\title{
CANCER OF THE STOMACH
}


Previous volumes in the series

Volume 1 Cancer of the Oesophagus

Edited by H. R. Matthews et al. 1987. 184pp.

Volume 2 Cancer of the Larynx

Edited by P. E. Robin et al. 1988. 238 pp. 


\section{Cancer of the Stomach}

John W. L. Fielding, MD, FRCS

Consultant Surgeon

Queen Elizabeth Hospital

Birmingham, England

and

Jean Powell, BSc, FIS

William H. Allum, MD, FRCS

John A. H. Waterhouse, MA, PhD, HonFFOM

Christopher C. McConkey, BSc

Regional Cancer Registry

Queen Elizabeth Medical Centre

Birmingham, England

with guest chapters by

M. Hockey, FRCS

J. Crocker, MA, MD, MRCPath

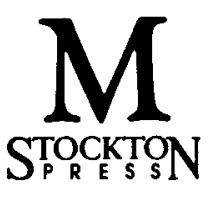


(C) The Authors 1989

Softcover reprint of the hardcover 1st edition 1989 978-0-333-47264-4

All rights reserved. No reproduction, copy or transmission of this publication may be made without written permission.

No paragraph of this publication may be reproduced, copied or transmitted save with written permission or in accordance with the provisions of the Copyright Act 1956 (as amended), or under the terms of any licence permitting limited copying issued by the Copyright Licensing Agency, 33-4 Alfred Place, London WC1E 7DP

Any person who does any unauthorised act in relation to this publication may be liable to criminal prosecution and civil claims for damages.

First published 1989

Published by

THE MACMILLAN PRESS LTD

Houndmills, Basingstoke, Hampshire RG21 2XS

and London

Companies and representatives

throughout the world

British Library Cataloguing in Publication Data

Cancer of the stomach.

1. Man. Stomach. Cancer

I. Fielding, John W. L. (John William Lewis) II.

Series

616.99 ' 433

ISSN 0954-7495

ISBN 978-1-349-10417-8

DOI $10.1007 / 978-1-349-10415-4$

Published in the United States and Canada by

Stockton Press

15 East 26th St, New York, NY 10010

ISBN 978-0-935859-80-5

Library of Congress Cataloging in Publication Data also available 


\section{Contents}

Foreword, by Professor M.R.B. Keighley

1 Introduction and Methods 1

$\begin{array}{llr}1.1 & \text { Introduction } & 1 \\ 1.2 & \text { Inclusion criteria } & 3 \\ 1.3 & \text { Data base } & 3 \\ 1.4 & \text { Validation procedures } & 3 \\ 1.5 & \text { Survival data } & 4 \\ 1.6 & \text { Statistical methods } & 5 \\ 1.7 & \text { Population } & 6 \\ \text { Figure } 1.1 & \text { 1961 and 1981 census population pyramid } & 8 \\ \text { Table } 1.7 .1 & \text { Comparison of social factors } \\ \text { Table } 1.7 .2 & \text { Population densities } \\ \text { Table } 1.7 .3 & \text { Populations used for the different time } \\ & \quad \text { periods } & 10 \\ 1.8 & \text { General arrangenent } & 11\end{array}$

2 Epidemiology: Demographic Aspects 12

$\begin{array}{lll} & \text { Summary } & 12\end{array}$

Table 2.1 Number per annum by sex 13

$\begin{array}{lll}\text { Figure 2.1 Number per annum by sex } & 14\end{array}$

Table 2.2.1 Incidence rates by quinquennium and sex 14

Table 2.2.2 Sex ratio of incidence rates by quinquennium 14

Figure 2.2 Incidence rates by quinquennium and sex 15

Table 2.3 Numbers and incidence rates by age and sex 16

$\begin{array}{lll}\text { Figure 2.3 Incidence rates by age and sex } & 17\end{array}$

Table 2.4.1 Numbers by age and quinquennium, males 18

Table 2.4.2 Numbers by age and quinquennium, females 19 
Table 2.5.1 Incidence rates by age and quinquennium, males

Table 2.5.2 Incidence rates by age and quinquennium, females

Table 2.5.3 Incidence rates by age, decennium and sex

Figure 2.5

Table 2.6

Incidence rates by age, decennium and sex

Figure 2.6

Table 2.7

Figure 2.7.1

Figure 2.7.2

Table 2.8.1

Age distribution by decennium and sex

Age distribution by decennium and sex

Incidence by birth cohort and sex

Incidence by birth cohort, males

Incidence by birth cohort, females

Incidence by quinquennium and subsite, males

Table 2.8.2 Incidence by quinquennium and subsite, females

Figure 2.8

Incidence by quinquennium, subsite and sex

Table 2.9.1 Incidence by subsite, males

Table 2.9.2 Incidence by subsite, females

Figure 2.9 Incidence by age, subsite and sex

Table 2.10 Social class

Table 2.11.1 Occupation, males

Table 2.11.2 Occupation by subsite, males

Table 2.12.1 Numbers and SRR by district and sex

Table 2.12.2 SRR by district related to social class

Figure 2.12.2 SRR by district related to social class

Figure 2.12.3 Map of West Midlands Region

Table 2.13 Incidence in different countries

\section{Histology}

$\begin{array}{ll}\text { Table } & 3.1 . \\ \text { Table } & 3.1 \\ \text { Table } & 3.2 \\ & \\ \text { Table } & 3.3 \\ \text { Table } & 3.4 \\ \text { Figure } 3.4 \\ \text { Table } 3.4 . \\ \\ \text { Table } 3.5 \\ \text { Figure } 3.5 \\ \text { Table } 3.6 \\ \\ \\ \text { Table } 3.7 \\ \text { Figure } 3.7 \\ \text { Table } 3.8 \\ \text { Figure } 3.8 \\ \text { Table } 3.9 \\ \text { Figure } 3.9\end{array}$

\section{Summary}

Histological categories

Proportions with no histology by quinquennium

Numbers and distribution with specified histology

Histological type by site

Annual survival by histological verification

Annual survival by histological verification

5 year survival by stage and histological

verification

Resected cases: annual survival by histology

Resected cases: annual survival by histology

Annual survival by differentiation

\section{Resected cases}

Annual survival by differentiation

Annual survival by differentiation

Distribution by stage and differentiation

Distribution by stage and differentiation

5 year survival by stage and differentiation Annual survival by stage and differentiation 


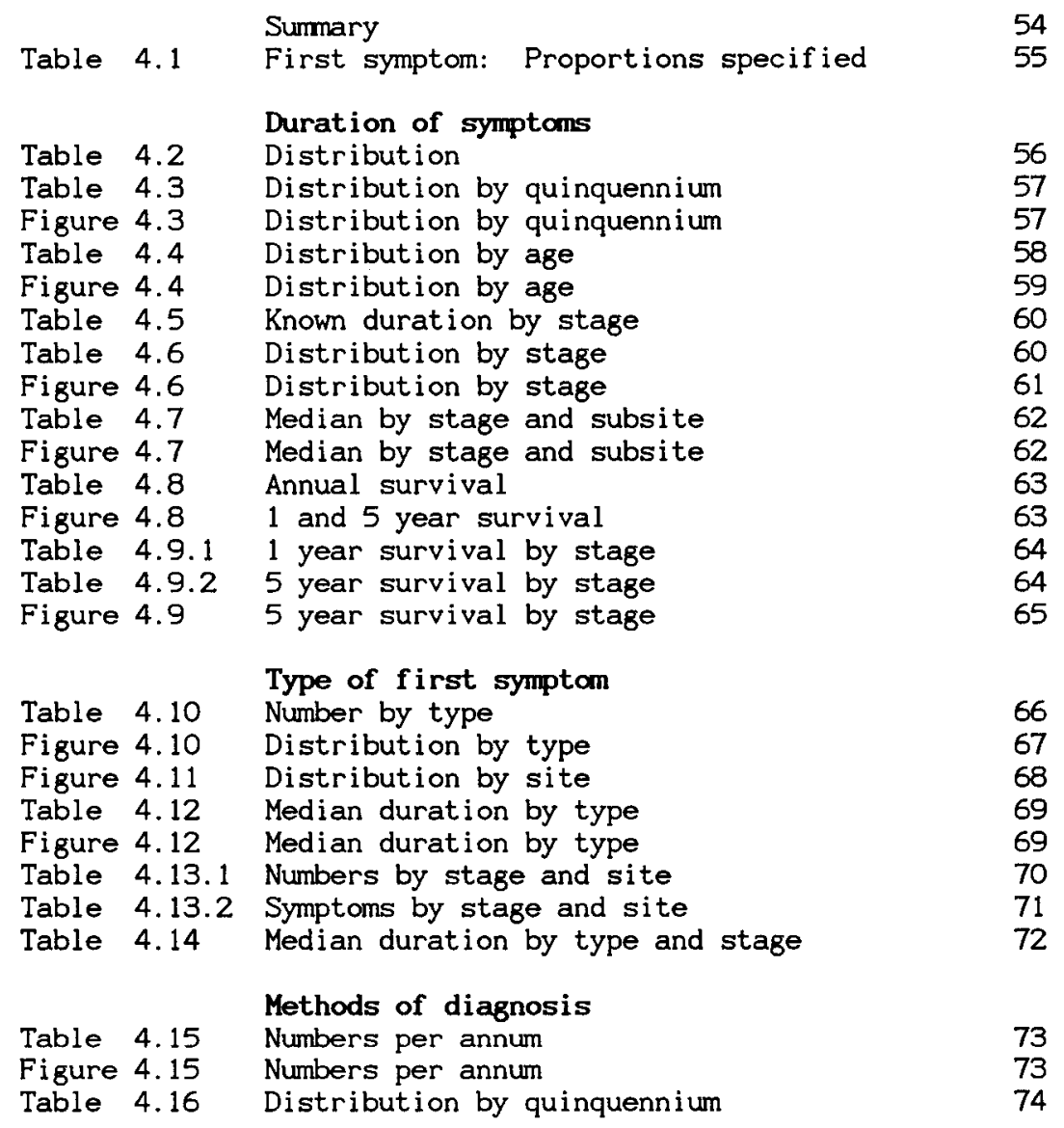

5 Overall Treatment and Survival 75

$\begin{array}{lll} & \text { Summary } & 75 \\ \text { Table } 5.1 & \text { Distribution by site and quinquennium } & 77 \\ \text { Figure 5.1 } & \text { Distribution by site and quinquennium } & 77 \\ \text { Table 5.2 } & \text { Distribution by stage and quinquennium } & 78 \\ \text { Figure 5.2 } & \text { Distribution by stage and quinquennium } & 79 \\ \text { Table 5.3 } & \text { Distribution by type of treatment } & 80 \\ \text { Figure 5.3 } & \text { Distribution by type of treatment } & 81 \\ \text { Table 5.4 } & \text { Distribution by treatment within site } & 82 \\ \text { Figure 5.4.1 } & \text { Distribution by treatment within site } & 83 \\ \text { Figure 5.4.2 } & \text { Unspecified site: treatment distribution } & 84 \\ \text { Figure 5.5 } & \text { Distribution by treatment and age } & 84 \\ \text { Table 5.5 } & \text { Distribution by treatment and age } & 85\end{array}$


Table 5.6 Figure 5.6 Table 5.7 Figure 5.7 Table 5.8 Figure 5.8 Table 5.9 Figure 5.9 Table 5.10 Table 5.11 Figure 5.11 Table 5.12 Figure 5.12 Table 5.13

Table 5.14

Table 5.15

Figure 5.15

Table 5.16

Table 5.17

Table 5.18
Distribution by treatment and quinquennium Distribution by treatment and quinquennium Annual rates, crude and age adjusted Annual rates, crude and age adjusted 89 Annual rates by quinquennium 90 Annual rates by decennium 91 5 year rates, crude and age adjusted by age 92 5 year rates, crude and age adjusted by age 93 5 year rates by quinquennium and site 93 Annual rates by stage 94 Annual rates by stage 95 5 year rates by stage and decade 96 Curatively resected: annual rates by decade 96 Curatively resected: 5 year rates by stage and decade

5 year rates, crude and age adjusted by treatment

5 year rates by treatment and decade $\quad 99$ Annual rates by treatment and decade 99 One month mortality by treatment and decade 100 Curatively resected: 5 year rates by type of gastrectomy and decade

101

Deaths within one month by type of gastrectomy and site

102

6 Stages I - IVA

103

Sumary

104

Table 6.1

Distribution and 5 year rates by stage

105

\section{Stage I by type of gastrectonty}

Table 6.2.1

Annual rates, crude and age adjusted

106

Annual rates

107

Table 6.2.2

Distribution and survival by sex

107

Table 6.2.3

Distribution and 1 month mortality by age

108

Table 6.2.4

5 year rates by age

Table 6.2.5 Distribution and survial by duration of symptoms

Table 6.2.6 Distribution and survival by site

Stage II by type of gastrectomy

Table 6.3.1 Annual rates, crude and age adjusted

Figure 6.3.1 Annual rates

112

$\begin{array}{lll}\text { Table 6.3.2 } & \text { Distribution and survival by sex } & 113 \\ \text { Figure 6.3.2 } & \text { Annual rates by sex } & 113\end{array}$

Table 6.3.3 Distribution and 1 month mortality by age 114

Figure 6.3.3 Distribution and 1 month mortality by age 115

Table 6.3.4 5 year rates by age 116

Figure 6.3.4 5 year rates by age 117

\section{6}

3

(1) 
Table 6.3.5 Distribution and survival by duration of symptoms

Figure 6.3.5

5 year rates by duration of symptoms

Table 6.3.6

Distribution and survival by site

Figure 6.3.6

1 month mortality and annual rates by site

Table 6.4.1

Stage III by type of gastrectomy

Figure 6.4.1

Annual rates, crude and age adjusted

122

Annual rates

122

Table 6.4 .2

Distribution and survival by sex

Annual rates by sex

123

Figure 6.4.2

Figure 6.4 .3
Table 6.4 .4

Distribution and 1 month mortality by age

123

Distribution and 1 month mortality by age

124

5 year rates by age

125

Figure 6.4.4

5 year rates by age

126

Table 6.4.5

Distribution and suvival by duration of symptoms

127

Figure 6.4.5

5 year rates by duration of symptoms

128

129

Table 6.4.6

Distribution and survival by site

130

Figure 6.4.6

1 month mortality and annual rates by site

131

Stage not known by type of gastrectomy

Table 6.5.1

Annual rates, crude and age adjusted

132

Figure 6.5.1

Annual rates

133

Table 6.5.2

Distribution and survival by sex

134

Annual rates by sex

135

Table 6.5.3

Distribution and 1 month mortality by age

Fi gure 6.5.3

Distribution and 1 month mortality by age

137

Table 6.5 .4

5 year rates by age

138

Figure 6.5.4

5 year rates by age

Table 6.5.5

Distribution and survival by duration of symptoms

139

Figure 6.5.5 Table 6.5.6

5 year rates by duration of symptoms

140

Distribution and suvival by site

141

Figure 6.5.6

1 month mortality and annual rates by site

142

143

\section{Stage IVA by type of gastrectomy}

Table 6.6.1

Annual rates, crude and age adjusted

144

Annual rates

145

Table 6.6.2

Distribution and survival by sex

146

Figure 6.6.2

Annual rates by sex

147

Table 6.6.3 Distribution and 1 month mortality by age

Figure 6.6.3 Distribution and 1 month mortality by age 149

Table 6.6.4 5 year rates by age

150

Figure 6.6.4 5 year rates by age

151

Table 6.6.5 Distribution and survival by duration of symptoms

Figure 6.6.5 5 year rates by duration of symptoms 153

Table 6.6.6 Distribution and survival by site 154

Figure 6.6.6 1 month mortality and annual rates by site 155 


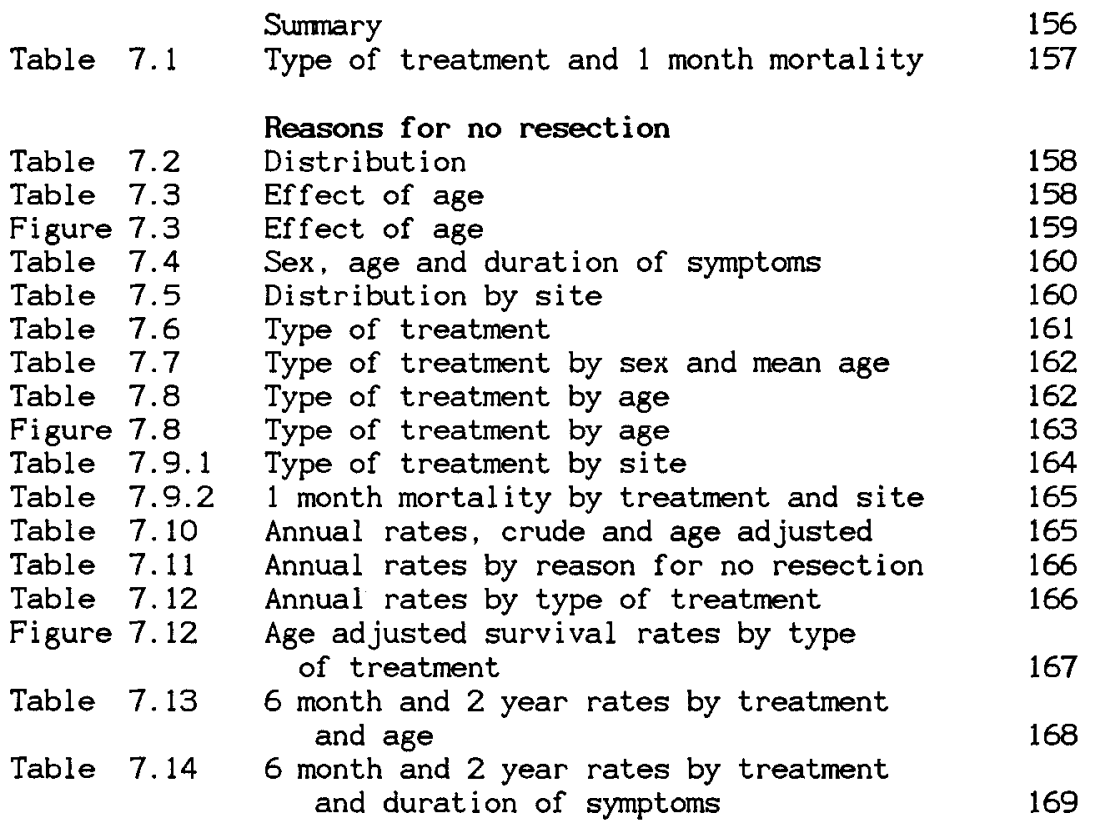

\section{Prognostic Factors}

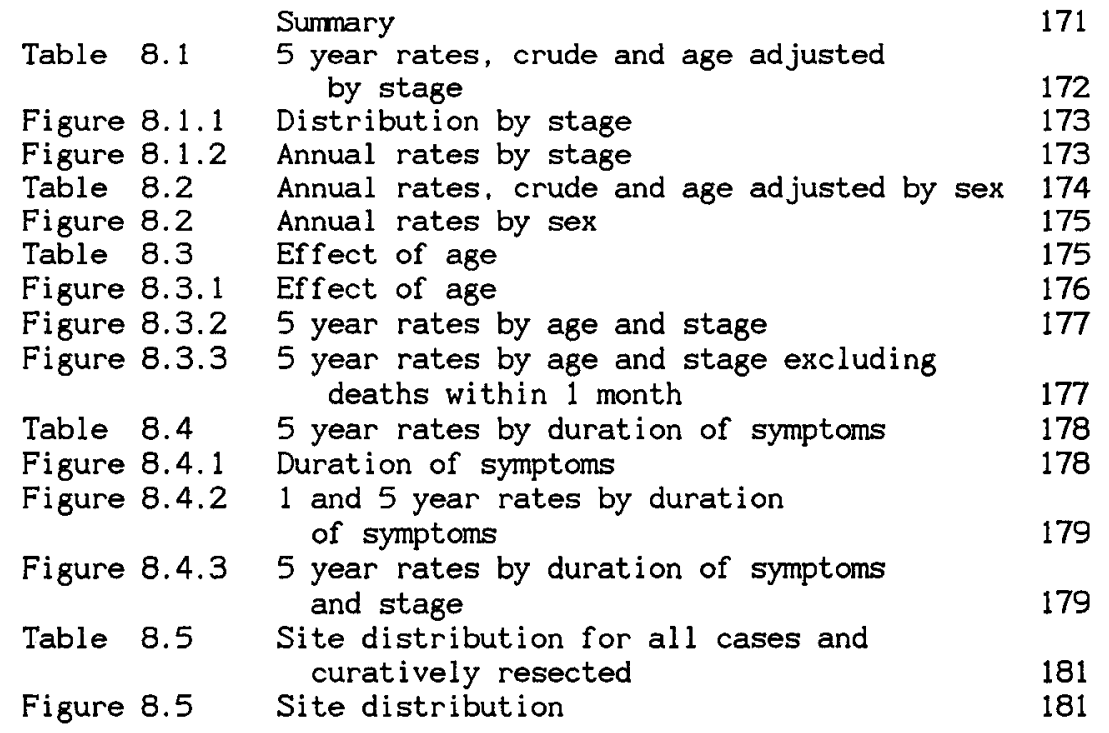


Table 8.6 Curatively resected: 5 year rates by site 182 Figure 8.6.1 Curatively resected: annual rates by site 182 Figure 8.6.2 Curatively resected: annual rates by stage and site

Type of curative gastrectomy

Figure 8.7 Annual rates 184

Table 8.8.1 5 year rates by stage 185

Table 8.8.2 5 year rates by stage excluding deaths 185

$\begin{array}{lll}\text { Figure 8.8.1 Annual rates by stage } & 186\end{array}$

Figure 8.8.2 Annual rates by stage excluding deaths within 1 month

Table 8.9 Effect of frequency of performance of gastrectomies on operative mortality and survival

\section{Table 9.1 \\ Table 9.2 \\ Table 9.3 \\ Table 9.4}

Table 9.5

Figure 9.5

Table 9.6

Figure 9.6

Table 9.7

Figure 9.7

Table 9.8

Figure 9.8

Table 9.9

Figure 9.9

Table 9.10

Figure 9.10
Surmary

Numbers by histological type

Clinical details of carcinoid, squamous cell carcinoma variants or melanoma

Sarcoma: numbers by histology and sex

Clinical details of sarcoma other than leiomyosarcoma

\section{Lei onyosarcoma}

Numbers by quinquennium and sex

Numbers per annum by sex

Numbers and incidence by age and sex

Incidence by age and sex

Age distribution by sex

Age distribution by sex

Annual rates by sex

Annual rates by sex

Annual rates by treatment and sex

Annual rates by treatment

Annual rates by treatment and sex excluding deaths within 1 month

Annual rates by treatment excluding deaths within one month
190

191

192

201

202

204

204

205

205

206

206

207

207

208

208

209

209

210
Sumary

Table 10.1 Number per annum

Figure 10.1.2 Comparison with gastric carcinoma

\section{i} 2

2

3


Table 10.2 Numbers and incidence by age and sex 214

Figure 10.2.1 Distribution by age and sex 215

Figure 10.2.2 Incidence by age and sex 215

Table 10.3 Histological classification 216

$\begin{array}{lll}\text { Table } 10.4 & \text { Numbers by quinquennium and sex } & 217\end{array}$

Table 10.5 Numbers by age and histology 218

Figure 10.5 Distribution by age and grade 218

Table 10.6 Numbers by stage and review status 219

Table 10.7 Annual rates, crude and age adjusted by sex 220

Figure $10.7 \quad$ Annual rates by sex 220

Table $10.8 \quad 5$ year rates by histological type 222

Table 10.9 Annual rates, crude and age adjusted by histological grade 223

Figure 10.9 Annual rates by histological grade 223

Table $10.10 \quad 5$ year rates, crude and age adjusted by age 224

Figure $10.10 \quad 5$ year rates by age 224

Table 10.11 Annual rates by stage 225

Figure 10.11 Annual rates by stage 226

Table 10.125 year rates, crude and age adjusted by 227

$\begin{array}{lll}\text { Table } 10.13 & \begin{array}{l}\text { Curatively treated: } 5 \text { year rates by } \\ \text { treatment and stage }\end{array} & 228\end{array}$

Figure 10.13 Curatively treated: annual rates by
treatment and stage

Table 10.14 5 year rates, crude and age adjusted by treatment, nodal involvement and review status

Appendix 1 Standardised Rates 231

$\begin{array}{lll}\text { A1.1 Standardised incidence rates } & 231\end{array}$

$\begin{array}{lll}\text { A1.2 Survival rates } & 234\end{array}$

A1.3 Age adjustment of survival rates 234

A1.4 Numerical illustrations 236

Appendix 2 Census and inter-censal populations 239

Appendix 3 Immunohistochemistry of gastric lymphoma
by J. Crocker

A3.1 Antibodies of value in diagnosis of gastric
lymphomas

A3.2 Suggested sequential scheme 243

A3.3 Results: Gastric lymphomas 1977-1981 244

$\begin{array}{ll}\text { References } & 246\end{array}$ 


\section{Foreword}

Gastric cancer is regarded by most clinicians as being a highly lethal malignancy. Five year survival figures in the UK, USA and Northern Europe rarely exceed $8 \%$ and yet there are some isolated centres that consistently report more favourable figures in each category of staged patients. Such observations may be due to case selection or conceivably due to improved treatment.

In order to avoid selection bias it is particularly valuable to report outcome from a stable, finite population base. The West Midlands Region's Cancer Registry is well equipped to provide exactly these data. The boundaries of the Region have remained stable and high quality data have been recorded since 1957 . It is, indeed. timely that the observations from the Registry between 1957 and 1981 are now available. The report highlights the variations in operative mortality at a time when audit and CEPOD (Confidential Enquiry into Perioperative death) reports are being considered by our politicians, and when the whole question of specialisation'is the subject of professional debate.

Subtle changes in the incidence of disease in relation to environmental factors has helped to shed some light on possible aetiological factors.

It is appropriate that this report should analyse in detail the results of surgical therapy within each stage of the disease. Surgery still remains the only reliable method of attempted cure. Improved staging methods are urgently needed, however, in selecting those patients in whom radical ablative gastrectomy and lymphadenectomy are justified. The authors are to be congratulated in producing a thoroughly informative work which helps to formulate rational treatment policies.

Sadly, unless clinicians strive to achieve earlier diagnosis of disease, much of our surgical efforts will be relatively fruitless. This monograph indirectly makes the case for screening dyspeptic patients and establishing specialist centres for training within which treatment modalities can be comprehensively compared.

M R B Keighley MS FRCS

Barling Professor of Surgery 


\section{Acknowledgements}

\section{The Cancer Research Campaign}

All the analytical work, and preparation of tables, graphs and diagrams by the small Monograph Research Team. has been wholly supported by the Cancer Research Campaign.

\section{Regional Cancer Registry}

The original data on which this series is based is entirely from the Birmingham and West Midlands Regional Cancer Registry.

We thank all those who - over many years - have given so generously of their time and expertise to ensure the completeness and accuracy of the data in the Registry. These include:

From the Registry:

All the staff both past and present.

From hospitals:

Consultant clinicians and pathologists

Administrators

Junior medical staf $f$

Laboratory technicians

Medical records staff

Medical secretaries

Throughout the Region:

Coroners

General Practitioners

Staff of Family Practitioner Committees

National ly:

The staffs of the Cancer Registration Sections of:

The of $\mathrm{f}$ ice of Population Censuses and Surveys.

The National Health Service Central Register.

From the University of Birmingham:

The staff of the Computer Centre.

All the illustrations were produced using Tellagraf on

the University's Honeywell Multics Computer.

From the Monograph Team:

Mrs. Vanessa Chadderton for her artistic and accurate preparation of the $f$ igures and the $f$ inal camera ready layout

Mrs. Judy Connor and Mrs. Margaret Williams for their painstaking preparation of the text and tables. 